\title{
Lapurdum
}

Euskal ikerketen aldizkaria | Revue d'études basques |

Revista de estudios vascos | Basque studies review

$16 \mid 2012$

Numéro XVI

\section{Informazio egitura, kuantifikatzaileak, eta beraien arteko eragina: Euskaratik ikerketa konparatibo batetarantz [ISQI proiektua]}

\section{Urtzi Etxeberria}

\section{(2) OpenEdition}

Journals

\section{Édition électronique}

URL : http://journals.openedition.org/lapurdum/2356

DOI : 10.4000/lapurdum.2356

ISSN : 1965-0655

Éditeur

IKER

\section{Édition imprimée}

Date de publication : 1 octobre 2012

Pagination : 69-91

ISSN : 1273-3830

\section{Référence électronique}

Urtzi Etxeberria, «Informazio egitura, kuantifikatzaileak, eta beraien arteko eragina: Euskaratik ikerketa konparatibo batetarantz [ISQI proiektua] », Lapurdum [Linean], 16 | 2012, Sarean emana----an 03 décembre 2014, kontsultatu 30 avril 2019. URL : http://journals.openedition.org/lapurdum/2356 ; DOI : 10.4000/lapurdum.2356 


\section{Informazio egitura, kuantifikatzaileak, eta beraien arteko eragina: Euskaratik ikerketa konparatibo baterantz [ISQI proiektua]}

Urtzi ETXEBERRIA

CNRS-IKER (UMR 5478)

\section{Sarrera ${ }^{1}$}

Kuantifikatzaileen gaineko ikerketak tradizionalki jakin-min eta arreta handia sortu eta lortu du semantikalari, logika ikertzaile, edo hizkuntzaren filosofia ikertzen dutenen artean. Jakin-min honen arrazoia kuantifikatzaileek erakusten dituzten propietate matematiko eta logikoei hertsiki lotua dago. Kuantifikatzaileen ikerketa, logika bera bezain zaharra dela esan daiteke, izan ere, ikerketa hau Aristoteles-en silogismoarekin batera abiatu zen duela hogeita hiru mende, eta bereziki kuantifikatzaileen esanahi eta inferentzi ezaugarrietan jarri du arreta. Kuantifikazioaren gaineko hizkuntzalaritzazko ikerketek hasera askoz beranduago izan bazuten ere, hizkuntza naturalen ikerketa teorikoan kuantifikazioaren inguruko galderek berebiziko garrantzia izan dute-eta izaten jarraitzen dute oraindik ere. Gauzak horrela, esan daiteke konposizionalitatearen hatsarrearen inguruko (ikus Garcia-Murga \& Rodriguez 2003 euskarazko aurkezpen baterako) zein kuantifikatzaileen esanahien inguruko ikerketak berebiziko garrantzia izan dutela hizkuntza naturaletako sintaxiaren eta semantikaren teoria orokorrerako (ikus Montague 1973, Heim 1982, besteren artean). Kuantifikazioa, hertsiki erlazionatuak dauden bi ikuspuntu desberdinetatik izan daiteke eta izan da ikertua: (i) barne ikuspuntu batetik, kuantifikatzaileetan beraietan oinarrituaz, hala nola, kuantifikatzaileen barne egitura morfosintaktikoa eta beraien oinarrizko propietate semantikoak ikertuaz; (ii) kanpo ikuspuntu batetik, kuantifikatzaileak agertzen diren testuingurua kontuan hartuaz, hau

1.- Ikerketa proiektu hau Agence Nationale de la Recherche-k (ANR) finantzatzen du.

Proiektuaren kodea ANR2011 JSH2 0041 da.

Partehartzaileak: Urtzi Etxeberria (CNRS-IKER), Ricardo Etxepare (CNRS-IKER), Anastasia Giannakidou (University of Chicago), Aritz Irurtzun (CNRS-IKER), Brenda Laca (Paris 8), Beñat Oyharçabal (CNRSIKER), Myriam Uribe-Etxebarria (University of the Basque Country), Georges Rebuschi (Université Sorbonne-Nouvelle). 
da, kuantifikatzaileek perpausean hartzen duten posizio sintaktikoa begiratuaz eta perpaus horretan agertu daitezkeen beste kuantifikatzaile batzurekin edo beste elementu (operatzaile semantiko) batzurekin eduki dezaketen harreman semantikoa ikertuaz.

Testuinguru honetan ulertu behar da beraz 'Information structure, quantifiers, and their interaction: From Basque to a comparative study' [Informazio egitura, kuantifikatzaileak, eta beraien arteko eragina: Euskaratik ikerketa konparatibo baterantz] izenburudun proiektuaren ekarpena. Bere helburu nagusia kuantifikazioa aipatu berri dugun kanpo ikuspuntu horretatik ikertzea izango da; zehazki, proiektu honen helburu nagusietako bat kuantifikatzaileak hainbat intonazio patroien eraginpean zer nolako portaera duten ikertzea izango da (hau da, informazio egitura desberdinen eraginpean nola portatzen diren, e.g. kuantifikatzaileak galdegai posizioan agertzen direnean). Arrazoi honexengatik, hau da, 'kanpo' azterketa bat egin ahal izateko, behar beharrezkoa izango da lehenengo eta behin kuantifikatzaileen portaera eta beraien berezko 'barne' propietateak ikertzea (ikus adibidez Etxeberria 2005, 2012). Proiektu honen azken helburu nagusia azterketa konparatibo bat egitearena izango da, izan ere, euskaraz gain, frantsesa, ingelesa, espainiera, eta greziera ere ikertuko dira.

Bost hizkuntza hauek ikertu nahi izatearen motibazioa hiru arrazoi nagusitan oinarritzen da: (i) hizkuntza familia ezberdinei dagozkie aztertuko diren hizkuntzak: euskara ahaiderik ezagutzen ez zaion eta jatorri zehaztugabea duen hizkuntza isolatu bat da; frantsesa eta espainiera hizkuntza erromantzeak dira; ingelesa hizkuntza germanikoa da (eta ziurrenik proiektu honetan ikertuko diren gaietan gehien aztertua izan den hizkuntza); azkenik, greziera hizkuntza heleniarra da. Bi hizkuntza erromantze ikertzeak ere badu bere arrazoia, izan ere ikertuak izango diren bi hizkuntza erromantzeak euskararekin harreman hertsi-hertsian daude, eta honek euskara modu batera edo bestera eragindua izan den ikusteko aukera ezin hobea eskaintzen digu, i.e. testuinguru geografiko desberdinetan euskararen portaera berdina den ala ez ikusteko aukera paregabea; (ii) bost hizkuntza hauek propietate tipologiko desberdinak ikertzeko aukera eskaintzen digute: euskara, Subjektu-Objektu-Aditz (SOA) hitzhurrenkeradun hizkuntza bezala deskribatua izan da, nahiz eta hitz-hurrenkeran askatasun handia erakusten duen; frantsesa eta espainiera SAO hizkuntza moduan deskribatuak izan dira, halere, badituzte desberdintasun garrantzitsu batzuk beraien artean (hitz-hurrenkera askeagoa da espainieraz frantsesez baino, espainierak pro-drop propietatea erakusten du, hau ez da gertatzen frantsesez, etab.); ingelesa ere SAO hizkuntza bat da, eta informazio egitura intonazioaren bitartez adierazten du; eta azkenik, grezierak perpaus neutraletan ASO eta SAO hitz-hurrenkerak onartzen ditu, eta ondorioz interesgarria izango da hitz-hurrenkeran eman daitezkeen aldaketek informazio egitura eta besarkadura erlazioetan duketen eragina nola aldatzen den ikustea; (iii) aztertuko diren hizkuntzek galdegaia markatzeko modu desberdinak erabiltzen dituzte: euskaraz, galdegaia perpausaren ezkerraldeko periferia deituan agertu ohi da, ingelesez, aldiz, informazio egitura intonazioa erabiliz markatzen da gehienetan, frantsesez eta ingelesez perpaus erdibitu 'cleft sentence' eta perpaus sasi-erdibitu 'pseudo-cleft sentence' deitu egiturak erabili daitezke galdegaia markatzeko, espainieraz berriz, galdegaia eskuinaldeko posizioan agertu ohi da, eta grezieraz, euskaraz bezala, intonazioa eta hitz hurrenkera erabiltzen dira informazio egitura markatzeko. Beraz, ikus daitekeenez, hizkuntzaz-hizkuntzako ikuspegi honek aukera ezin hobe bat eskaintzen digu sortu(ko) zaizkigun ikerketa galderei erantzun bat ematen saiatzeko. 


\section{Zergatik proiektu hau? Zer ekarriko digu?}

\subsection{Kuantifikazioa euskaraz}

Euskal hizkuntzalaritza euskararen morfosintaxiaren atal batzuetan zentratu da nagusiki, e.g. ergatibotasuna, informazio egiturazko propietateak, edo pro-drop delako propietatea. Salbuespen batzuk gora behera (e.g. Goenaga 1991, Eguzkitza 1993, Laka 1993, Artiagoitia 1997, 1998, 2002, 2003, 2004, 2006, 2012, Eguren 2006, 2012, i.a.), euskal izen sintagmaren azterketari ez zaio arreta handirik eskaini, eta are gutxiago adierazpide kuantifikazionalei (cf. Etxeberria 2005, 2008, 2009, 2012). Etxeberriak buruturiko ikerketa euskal (eta beste hizkuntza batzuetako) kuantifikatzaileen barne egituran eta egitura honen analisi sintaktiko zein semantiko bat burutzen zentratu da bereziki. Kontuan izanik kuantifikatzaiale sendo deituen ${ }^{2}$ domeinua testuinguruak murrizten duela, Etxeberriaren ikerketaren ekarpen nagusia (ikus baita ere Giannakidou 2004, Etxeberria \& Giannakidou 2009, agertzeko) kuantifikatzaileen domeinuaren murriztapena hizkuntza batzuetan ageriko sintaxian gertatzen dela erakustea izan da, determinatzaile definituaren presentziaren bitartez hain zuzen ere, (e.g. euskaraz, grezieraz; baita St'át'imcets hizkuntza saliziarrean ere). Ideia hau Westerståhl (1984) lanean oinarrituz eraikitzen da, non artikulu definituak testuinguru-multzo deitua ematen duela proposatzen den. Etxeberriak proposatu analisi hau Zenbatzaile Orokortuen Analisi estandarra ('Generalized Quantifier Theory'; ikus besteren artean Montague 1974, Barwise \& Cooper 1981, Zwarts 1986, Parte 1987, Keenan 1987, 1996, Keenan \& Westerståhl 1997) egokia delako ideiaren aldeko argudiotzat hartu behar da (contra Matthewson 2001).

Kuantifikatzaileak eta beraien barne egitura aztertu dituzten lan hauetaz gain, kuantifikazioa (euskaraz behintzat) ez da sistematikoki ikertua izan kanpo ikuspegi batetik. Hain zuzen ere, helburu hau oinarritzat hartuta ikerketa proiektu hau jarraian zehazten diren galderak erantzuten saiatuko da: (i) testuinguru berrietan, besarkadura erlazioak existitzen ote diren ikertu bi kuantifikatzaile edo gehiago dituzten perpausetan (e.g. ingelesez gertatzen den moduan; ikus 3 atala), (ii) besarkadura erlazioak existitzen ote diren ikertu bi kuantifikatzaile edo gehiago dituzten perpausetan eta kuantifikatzaile horietako bat informazio egiturak eragindua denean, e.g. fokalizatua edo topikalizatua. Kuantifikatzaile arruntez gain, ezezko eta galdera kuantifikatzaileen besarkadura portaera ere ikertua izango da proiektu honetan.

Jasoko ditugun emaitzak erabilgarriak eta interesgarriak izango dira sintaxilarientzat, semantikalarientzat, intonaziozko fonologia ikertzen dutenentzat, morfologilarientzat eta baita euskal hizkuntzan interesa duten hizkuntzalari tradizionalagoentzat ere. Ikerketa proiektu honekin lortuko diren emaitzak ikerketa tipologikoarentzat hutsune bat betetzera ere etorriko dira, izan ere, modu koherente batean aurkeztuko du euskal kuantifikatzaile sistema.

\subsection{Ikerketa konparatiboa}

Uste dugu beharrezkoa dela hizkuntzaz hizkuntzako kuantifikatzaileen gaineko ikerketa bat burutzea, izan ere, azken hogeita hamar urteetan arduratu gaituzten gaiak eta galderak hizkuntza indo-europarrei, bereziki ingelesari eta alemanari, erlazionatuak izan 
baitira. Azkenaldian, begi-bistakoa eta agerikoa bihurtzen ari da gure ikerketa munduko hizkuntza gehienetan existitu ere egiten ez diren arazoek zuzendu dutela. Adibidez, Zenbatzaile Orokortuen Teoria deituak sintaxi jakin baten (izen sintagma bat izatea) eta semantika jakin baten (zenbatzaile orokortu bat denotatzea) elkarrekikotasun baten existentzia asumitzen du, baina hizkuntzaz hizkuntzako ikerketak agerian utzi du aldakortasun ikaragarria dagoela hizkuntza desberdinetako kuantifikazioan ikerketa zehatzago baten beharrean gaudela aditzera emanez (ikus Bach et al 1995, Matthewson 2008a, Keenan \& Paperno 2012; ikus eztabaidarako Matthewson 2001, 2008b, 2013, Giannakidou 2004, Etxeberria 2005, Etxeberria \& Giannakidou 2009, agertzeko).

Kuantifikatzaileen barne egitura aztertu dituzten hainbat lan badiren arren (cf. Bach et al. 1995, Matthewson 2008a, Keenan \& Paperno 2012), kuantifikatzaileak kanpo ikuspegi batetatik ikertu dituzten hizkuntzaz hizkuntzako lan gutxi daudela esan daiteke (cf. Szabolcsi 1997, Keenan \& Paperno 2012; cf. Huang 1982, Lee 1986, Aoun \& Li 19891993 txineraren inguruko lanentzat; Szabolcsi 1997, Szabolcsi \& Brody 2003 hungarierarentzat, Pafel 2005 alemanierarentzat; Etxeberria 2002, 2012 euskararentzat). Ondorioz, proiektu honen ekarpena interesgarria eta garrantzitsua izango da euskara, frantsesa, ingelesa, espainiera eta grekerako kuantifikatzaileak modu konparatibo batean ikertzeko helburua duelako. Gainera, ikerketa konparatibo honek kuantifikatzaileen besarkaduraren inguruan dauden azterketek lortuko diren datuen berri emateko balio ote duten ondorioztatzeko aukera eskainiko digu. Eta noski, dagoeneko esistitzen diren azterketek datuen berri eman ezin badute, datuen azalpen bat emateko gaitasuna izango duen analisi berri bat proposatzea ere helburu bihurtuko da.

\subsection{Interfaze ikuspegia}

Kuantifikatzaileen propietate logikoak (ikus besteak beste Barwise \& Cooper 1981, Keenan \& Stavi 1986) eta kuantifikatzaileen barne egitura sintaktikoa ondo ikerturik dauden arren, kuantifikatzaileak ez dira ondo ikertuak izan sintaxia-fonologia interfazean (cf. Jackendoff 1972, Büring 1997, Krifka 1998, Kadmon 2001, Baltazani 2002, Herburger 2002, Etxeberria \& Irurtzun 2004, Jackson 2007). Ikerketa proiektu hau kuantifikatzaileei intonazio patroi desberdinek nola eragiten dieten ikertzen ere zentratuko da. Azken helburua ez da bakarrik besarkadura harremanak informazio egiturak nola eragiten dituen ikustea, baita ere kuantifikatzaile ahul deituak edo numeralak—zeinak irakurketa kardinal eta proportzional baten artean anbiguoak diren (cf. Milsark 1977; ikus baita ere 3.2 atala)_fokalizatuak izateak zer eragin duen beraien interpretazioan ikertzea. Badirudi intonazio patroi desberdinak testuinguru jakin batzuetarako bakarrik direla egokiak, eta patroi hauek anbiguotasuna desegiten dutela (ikus 3 atala).

\subsection{Informazio egitura eta sintaxi-fonologia interfazea}

Informazio egituraren gaineko azterketak bi talde nagusitan bana daitezke (ikus Tajsner 2008 eztabaida orokorrago bat ikusteko): (i) informazio egituraren sintaxiaren gaineko ikerketak (i.e., ezker periferiaren kartografiarren ikerketak; ikus Ortiz de Urbina 1989, Rizzi 1997), eta (ii) sintaxi-fonologia interfazearen ikerketa (i.e., F-Egituaren 'F-structure' eta azentu nuklearraren kokapenaren inguruko ikerketak; cf. Cinque 1993, Zubizarreta 1998, Reinhart 2006). Gainera, galdegaiaren eta mintzagaiaren semantika ikertzen duten ikerketa asko eta askok perpausaren intonazioa kontutan hartu izan dute (ikus besteak beste Rooth 1985, Büring 1997, 1999, 2003, Schwarzchild 1999, Krifka 2004 edo Elordieta \& Irurtzun 2010). 
Halere, normalean, modu honetako ikerketek osagai sintaktikoa gainetik begiratu baino ez dute egiten, arreta oso gutxi emanaz elementu bakoitzak bete dezakeen posizio sintaktiko zehatzari (ikus Kratzer \& Selkirk 2007 salbuespen baterako). Proiektu honen helburuetako bat ere bada beraz sintaxi-fonologia interfazea ikertzea gramatikaren moduluek zein lan egiten duten zehazteko. Helburu hau jomuga hartuta, hizkuntzen arteko ikerketa konparatiboa oso garrantzizkoa izango da.

\section{Orainartekoak}

\subsection{Kuantifikatzaileen besarkadura}

Ikasle guztiak bezalako Kuantifikatzaile Sintagmek ez diete entitate zehatzei egiten erreferentzia (izen bereziek egiten duten moduan), eta propietateen multzo bat denotatzen dute (i.e. Kuantifikatzaile Orokortuak; Montague 1974, Barwise \& Cooper 1981; ikus baita ere Etxeberria 2005, et seq.).

Jonek ikasle guztiak miresten ditu

Goiko perpausaren esanahia (2)n adierazten den bezala errepresenta daiteke, non $x$ aldagaia kuantifikatzailearen arabera interpretatzen den, kasu honetan kuantifikatzaile unibertsala den guzti-ren arabera ( $\forall$ moduan adierazia formulan).

$$
\forall \mathrm{x} \text { (mirestu j,x): } \mathrm{x} \text { guztientzat, Jonek x miresten du. }
$$

Kuantifikatzaile Sintagmei erreferentzia egiteko operatzaile terminoa ere erabili izan da. Bi operatzailedun perpausetan (kuantifikatzaileak kasu honetan), perpausari ematen zaion formulan operatzaileek duten ordenak garrantzi handia du, ordena hauxe baita beraien arteko besarkadura adieraziko duena, eta besarkadura erlazio hauek esanahian eragiten dute. Horrela, ingeleseko (3) bezalako perpaus bat logikoki (4a) edo (4b) bezala adierazi daiteke. Kuantifikatzaile baten besarkadura logikoa formula batean kuantifikatzaile horren eskuinetara dagoen guztia dela esan genezake: (4a)n every teacher 'irakasle guztiek' ( $\forall$ bezala adierazia) some student 'ikasleren bat' elementuaren ( $\exists$ bezala adierazia) gaineko besarkadura hartzen duen bitartean, (4b)n some student da every teacher kuantifikatzailearen gaineko besarkadura hartzen duena. (4a)k irakasle guztiek ikasle desberdin bat miresten dutela adierazten du; (4b) $\mathrm{k}$ adierazten duena berriz zera da, badela ikasle jakin bat (Mikel esaterako) zeina irakasle guztiek miresten duten.

$$
\text { Every teacher admires some student. }
$$

guzti irakasle mirestu -ren bat ikasle

'Irakasle guztiek ikasleren bat miresten dute's

3.- Agerikoa da euskarazko itzulpenak ez dituela ingeleseko perpausak onartzen dituen bi irakurketak baimentzen. Euskaraz, irakurketa posible bakarra (4a)koa litzateke; ikus Etxeberria (2002, 2012); ikus baita ere Etxeberria \& Irurtzun (prestatzen). 
a. $\forall x \exists y$ (Mirestu xy): 'x guztientzat bada y bat eta $x-k$ y miresten du'.

b. $\exists y \forall x$ (Mirestu xy): 'bada y bat eta $x$ guztiek y miresten dute'.

(4a)ko formulan, every teacher-ek besarkadura zabala duen bitartean some student-ek besarkadura estua du; (4b)n aldiz, some student objektuak alderantzizko besarkadura zabala (wide inverse scope) deitua lortzen du. Ohar zaitezte formula honetan, kuantifikatzaileen (operatzaile) hurrenkera (3) perpausean kuantifikatzaileek erakusten dutenaren kontrakoa dela.

Operatzaileen besarkadura sintaxian ere adierazten da, izan ere, asumitu izan da kuantifikatzaileak (edo operatzaileak) sintaxi egituran beraien besarkadura zehazten duten tokietara mugitu behar direla. May-k $(1977,1985)$ hau lortzeko Kuantifikatzaileen Igoera ('Quantifier Raising') deitzen duen mugimendua proposatzen du, zeina interpretazio semantikoa gauzatzen den Forma Logikoa (Logical Form) deituriko mailan gertatzen dela argudiatzen duen. Modelo gehienek asumitzen dute Kuantifikatzaileen Igoera Forma Logikoan gertatzen den prozesu bat dela, izan ere, ingelesez, kasu askotan behintzat, ageriko sintaxian osagarriek erakusten duten hurrenkera ez dator bat osagarri horiek izan ditzaketen besarkadura erlazioekin. Kuantifikatzaileen Igoera prozesuaren arabera, kuantifikatzaileak beraien argumentu posiziotik besarkadura hartzen duten posizio batetara mugitzen dira, $x$ aztarna bat utziaz sorrerako posizioan. Kuantifikatzailearen besarkadura bere O(sagarri)komando domeinuak zehazten duela asumitzen da, i.e. kuantifikatzaileak menpean hartzen dituen adabegi sintaktikoak. Hauxe da kuantifikatzaileen besarkaduraren teoria sintaktikoaren oinarria, besarkadura teoria gehienek, kontrajarriak izan arren, onartzen dutena (ikus besteren artean May 1977, 1985, Aoun \& Hornstein 1985, Aoun \& Li 1989, 1993, Hornstein 1995, Beghelli \& Stowell 1997, Fox 2000; ikus Szabolcsi 2000, 2010, Ruys \& Winter 2011, teoria hauen laburpen baterako).

Zenbait ikertzaileren arabera Kuantifikatzaileen Igoera arau uniforme bat da, hau da, igoera mugimendua kuantifikatzaile guztiei modu berean ezartzen zaie. Kuantifikatzaile Sintagmak perpausaren adabegiari, hau da, gaur egungo Denbora Sintagmari (DenbS), edo Aditz Sintagmari (AS) eransten zaizkio Forma Logikoan, eta hauxe izango da anbiguotasuna adieraztea ahalbidetuko duena. Har ezazue (5) adibidea. Perpaus honek (6a)ko ala (6b)ko deribaziok izan ditzake. (6a)ko deribazioaren arabera every teenager'nerabe guztiak' subjektuak some singer 'abeslariren bat' objektua O-komandatzen du eta honen gaineko besarkadura hartzen du. (6b)ko deribazioaren arabera aldiz, some singer 'abeslariren bat' objektuak every teenager 'nerabe guztiak' subjektua O-komandatzen du subjektua baino goragoko posizio sintaktiko batetara igo delako.

Every teenager admires some singer. guzti nerabe mirestu -ren bat abeslari

'Nerabe guztiek abeslariren bat miresten dute'
a. [every teenager ${ }_{1}$ [some singer ${ }_{2}\left[\mathrm{t}_{1}\right.$ admires $\left.\left.\left.\mathrm{t}_{2}\right]\right]\right]$
b. [some singer ${ }_{2}$ [every teenager ${ }_{1}\left[\mathrm{t}_{1}\right.$ admires $\left.\left.\left._{2}\right]\right]\right]$

Beghelli (1993), Reinhart (1995, 1997), Beghelli \& Stowell (1997) eta Szabolcsi (1997) lanek eman zuten aditzera lehenengo aldiz kuantifikatzaileen besarkadura portaerak 
kuantifikatzaileen berezko propietateen araberakoak zirela (ikus baita ere Kroch 1974 , Ioup 1975 eta Liu 1990). Beghelli, Stowell, eta Szabolcsi-ren proposamenaren arabera, kuantifikatzaileek, beraien berezko propietateen arabera posizio sintaktiko zehatzak beteko dituzte Forma Logikoan, eta posizio sintaktiko hauexek izango dira kuantifikatzaileen besarkadura zehaztuko dutenak. Beste modu batetara esanda, besarkadura, kuantifikatzaileek beraien tasunak erkatzeko proiekzio funtzional jakin batzuetara egindako mugimenduen emaitza izango da. Modu honetara, posible da azaltzea bi kuantifikatzailedun perpaus guztiek interpretazioa anbiguoak ez dituztela ematen (e.g. two students passed fewer than six classes 'bi ikaslek sei azterketa baino gutxiago gainditu zituzten', edo most of the students read every book 'ikasle gehienek liburu guztiak irakurri zituzten'; ikus baita ere 3 oin-oharra).

Beste ikerketa lerro garrantzitsu bat Besarkaduraren Ekonomia 'Scope Econnomy' deitua da (Fox 2000, Reinhart 2006), non Kuantifikatzaileen Igoera mugimendua ondorio semantiko bat duen kasuetan baino ez den onartzen. Ondorioz, ikertzaile hauek kuantifikatzaileek izango dituzten Kuantifikatzaileen Igoera aukeretan murriztapenak jartzen dituzte. Fox-ek (2000) bi egitura desberdintzen ditu ingelesarentzako: (i) besarkadurari dagokionean informatiboa ( $a$ girl loves every boy 'neska batek mutil guztiak maite ditu'), eta (ii) besarkadurari dagokionean ez-informatiboa (Jon loves every boy 'Jonek mutil guztiak maite ditu'). Gauzak horrela, Fox-ek dio Besarkadura Aldatze Operazioek 'Scope Shifting Operations' ez dutela eraginik izango besarkadurari dagokionean ez-informatiboak diren perpausetan, izan ere, egoera honetan, Besarkadura Aldatze Operazioek ez dute efektu semantikorik sortzen perpausaren interpretazioan. Beraz, besarkadurari dagokionean ez-informatiboak diren perpausak azaleko egiturak zehazten dituela esan daiteke.

Halere, ohar zaitezte aipatu ditugun teoria hauek ez dutela prosodiaren eraginik kontutan hartzen. Ondorioz, zaila litzateke jakiten intonazioak (7) bezalako perpausak desanbiguatzeko garaian izan dezakeen efektua (ikus Jackendoff 1972). (7)ko adibidea anbiguoa da (7a)-n eta (7b)-n adierazten diren interpretazioen artean, kuantifikatzailearen eta ezeztapenaren besarkadura erlazio posibleen arabera.
All the men didn't go.
guzti D gizon.pl aux.ez joan
'Gizon guztiak ez ziren joan'4
a. all > not: ez zen batere gizonik joan
b. not > all: gizon batzuk ez ziren joan

Aldiz, intonazioaren eragina kontutan hartu bezain laster ((8) adibidean marren bitartez adierazten den bezala) ohartzen gara (7) perpausaren bi irakurketetatik bakarra geratzen zaigula eskuragarri. Büring (1997) eta Krifka (1998) lanek mintzagai hanpatua 'contrastive topic' deitua erabiltzen dute datu hauen berri emateko, zeinak, egile hauen arabera, (8a)n adierazten den alderantzizko besarkadura ahalbidetzen duen.

4.- Ohartu bedi irakurlea euskarazko itzulpena ez dela anbiguoa eta (7b)ko interpretazio baino ez dezakeela lortu. 


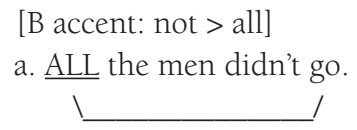

(Ikus besteren artean Martí 2001, Baltazani 2002, Kennelly 2003, Etxeberria \& Irurtzun 2004, edo Jackson 2007 intonazioak kuantifikatzaileen besarkaduran izan dezakeen eragina zein izan daitekeen ikusteko).

Lehenago esan dugun bezala, euskaraz, kuantifikatzaileak barne ikuspegi batetik ikertuak izan diren arren (Etxeberria 2005, 2008, 2009, 2012), kuantifikatzaileak kanpo ikuspegi batetik ikertzen duen lanik ia ez dago (ikus Etxeberria 2002 non kuantifikatzaileen besarkadura harremanak ageriko sintaxian ezartzen direla argudiatzen den; ikus baita ere Elordieta 2001). Proiektu honen helburuetako bat, ondorengo galderei erantzun bat emanez, zulo hau betetzea izango da: (i) testuinguru berrietan, besarkadura erlazioak existitzen al dira euskarazko bi kuantifikatzaile edo gehiago dituzten perpausetan? Hau da, irakurketa anbiguoak sortzen al dituzte besarkadura harremanen ondorioz (ingelesez gertatzen den bezala)?, (ii) besarkadura erlazioak existitzen al dira bi kuantifikatzaile edo gehiago dituzten perpausetan eta kuantifikatzaileetako bat informazio egiturak eragindua denean, i.e. fokalizatua (edo topikalizatua) denean? (iii) kuantifikatzaileek besarkadura aldakortasuna erakusten al dute ezeztapenarekin eta galdera hitzekin harremanetan jartzean?

\subsection{Informazio egitura}

'Informazio egitura' terminoak perpaus bat diskurtso batean ainguratua izan dadin (i.e. diskurtsoko zein zati den informazio berritzat eta zein zahartzat hartzen dena, ikus, e.g. Vallduví 1993, Erteschick-Shir 2007) perpaus hori sortzeko erabiltzen den moduari egiten dio erreferentzia. Ondorioz, informazio egitura—nahiz eta fokalizazioak gramatikazko efektu asko erakusten dituela jakina den—gramatikaz kanpo dagoen zerbaiten moduan hartu izan da, nolabait diskurtsoaren edo estiloaren alorrari dagokion zerbaiten moduan. Fokalizazioak erakusten dituen gramatikazko efektuen artean ondorengoak aipatu ditzakegu, besteren artean: (i) euskara, ingelesa edo italiera bezalako hizkuntzetan azentu nuklearraren kokatze ereduak, (ii) nederlandarra, hungariera, euskara edo zapotec hizkuntzetako lekualdatze sintaktikoa, (iii) tuki, manding edo euskaraz erabiltzen diren partikula morfologiko berariazkoak (ikusi Kiss 1995 eta Rebuschi \& Tuller 1999).

Azken urteetan, galdegaiak eragiten dituen efektu sintaktikoen berri emateko bi analisi hedatu dira nagusiki (ikus Tajsner 2008 errebisio kritiko batetarako): alde batetik 'ezker periferiako' analisia edo analisia 'kartografikoa' deitua genuke (cf. Brody 1990, Ortiz de Urbina 1995 eta Rizzi 1997). Jakina da hizkuntza batzuetan galdegaiak egitura sintaktikoan eragiten duela eta fokalizatua den elementua egitura horren ezker aldean, ezker periferian, agertzen dela. Euskara da portaera hau erakusten duten hizkuntzetako bat, galdegai sintagma aditzaurreko posizioan agertzen baita.
a. Galdegai zabala:
Peiok txangurru bat erosi du
b. Galdegai hertsia:
[Txangurru bat $]_{\mathrm{F}}$ erosi du Peiok 
Posizio aldaketa hauen berri emateko, analisi mota honek ezker periferian legokeen buru funtzional baten beharra proposatzen $\mathrm{du}\left(\mathrm{C}^{\circ}, \mathrm{Foc}^{\circ}, \mathrm{F}^{\circ}\right.$ edo besteren bat teoriaren arabera) zeinak fokalizatua den elementua bere espezifikatzaile posiziora erakartzen duen. Aditza berriz berariazko posizio funtzional horren burura igoko da fokalizatua den XSintagmarekin bere $[+\mathrm{F}]$ tasuna erkatzera Espezifikatzaile-Buru erlazio baten bitartez, (10)en erakusten den bezala.

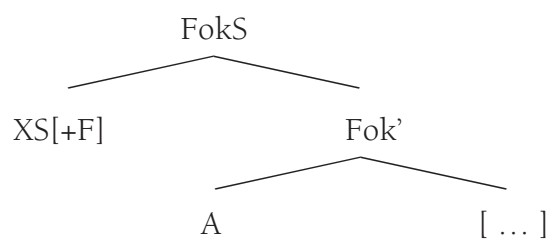

Buru funtzional hau diskurtso nozioak kodetzen dituzten beste buru funtzional batzurekin erlazionatu izan dute hizkuntzalari batzuk, e.g. L. Rizzik (1997) ezker periferiarentzat proposaturiko kartografian ikus daitekeen bezala:

$$
\text { Force ... (Topic) ... (Focus) ... Fin ... IP }
$$

Labur-labur esateko, analisi mota hau galdegaiak bultzatzen dituen mugimendu sintaktikoez arduratzen da, korrelatu fonologikoak kontutan hartu gabe.

Beste ikerketa lerro nagusia 'Azentu Nuklearraren Araua' deituan oinarritzen denarena da, cf. Zubizarreta (1998) edo Reinhart (2006) beste askoren artean. Analisi honek aurretik aipatu analisiaren kontrako ikuspuntua hartzen du, izan ere, galdegaiaren alderdi fonologikoan (azentu nuklearrean) jartzen baitu arreta. Azentu bakar baten lekutzea Galdegai-Egitura (G-Egitura) hainbatekin erlazionatu daiteke (cf. (12)).

a. John bought $[\text { WATER }]_{\mathrm{F}}$

b. John [bought WATER $]_{\mathrm{F}}$

c. [John bought WATER $]_{\mathrm{F}}$

Analisi honen arabera, kasu hauetan elementu baten izaera fokala azentuaren lekutzetik deribatzen da (i.e. azentu nuklearra duen elementua galdegai moduan interpreta daiteke) eta horrelako kasuetan 'galdegai proiekzio' delakoa izango genuke. Ondorioz, ikerlerro honek, fokalizazioak bultzatzen dituen toki aldaketen berri emateko, 'prosodiazko-mugimenduak' proposatzen dituzte informazio egiturazko propietateak dituzten hizkuntzetan-hala nola nederlandera, espainiera, bulgariera, edo euskara (ikus besteren artean Zubizarreta 1998, Elordieta 2001, Reinhart 2006).

Euskarari dagokionean, informazio egitura eztabaidagai oso garrantzitsua izan da eta oraindik da euskal hizkuntzalaritzaren barnean, izan ere euskarak galdegaia markatzeko konfigurazio sintaktiko jakin bat erabiltzeaz gain, azentu nuklearra eta marka morfologiko jakin batzuk ere erabiltzen ditu testuinguru batzuetan (izenordain indartuak, 'egin' aditza, etb.) (cf. i.a., Azkue 1923, Altube 1929, Mitxelena 1981, Rebuschi 1983, Ortiz de Urbina 1989, Etxepare \& Ortiz de Urbina 2003 eta Irurtzun 2007). Galdegaiak euskaraz efektu 
fonologiko, semantiko eta morfosintaktikoak erakusten dituenez, euskara ikertzea lagungarria izango da galdegaiaren eta gramatikaren moduluen elkar-eragitea ikertzeko.

\section{Aztertuko diren datuak: euskara eta beste}

Atal honek 'Information structure, quantifiers, and their interaction: From Basque to a comparative study' [Informazio egitura, kuantifikatzaileak, eta beraien arteko eragina: Euskaratik ikerketa konparatibo baterantz] izenburudun ikerketa proiektu honek ikertzeko asmoa duen datuen berri ematea du helburu.

\subsection{Kuantifikatzaile-kuantifikatzaile elkareragiteak}

Dagoeneko ikusi dugu (3.2 atalean) perpaus batean bi kuantifikatzaileren presentziak irakurketa anbiguoak bultza ditzakeela (hizkuntza batzuetan behintzat). Euskaraz, ez du ematen gauzak horrela direnik, ez beti behintzat; izan ere, euskara besarkadura harremanak ageriko sintaxian ezartzen dituen hizkuntza baten moduan deskribatua izan da (cf. Etxeberria 2002, 2012; ikus baita ere Elordieta 2001). Adibidez, (13)ko perpausa-indefinitu batekin dugun subjektu posizioan eta kuantifikatzaile unibertsal batekin objektu posizioan-, subjektuak besarkadura zabala duela interpretatu daiteke soilik, hau da, argitaratzaile bakar bat da eskuizkribu guztiak irakurri dituena. Ondorioz, liburu guztiak objektua ezin daiteke besarkadura zabalarekin interpretatu, hau da, perpausa ezin daiteke ulertu eskuizkribu bakoitzeko argitaratzaile desberdin batek irakurri izan balu bezala. Irakurketa hauek (13a,b) adieraziak daude.

Ikasle batek liburu guztiak irakurri zituen.

a. $\sqrt{ } \exists x \forall y$ (Irakurri $x y)$ : 'bada $x$ bat eta $x$ horrek y guztiak irakurri ditu'.

b. * $\forall y$ $\exists$ x (Irakurri xy): 'y guztientzat bada $\mathrm{x}$ desberdin bat eta $\mathrm{x}-\mathrm{k}$ y irakurri du'.

Interesgarria da baita ere aipatzea perpausean erabiltzen diren kuantifikatzaileek eragina dutela bultza ditzaketen interpretazioetan. Horrela, (14) bezalako perpaus batean, non objektu posizioan guzti-ren ordez kuantifikatzaile distributiboa den bakoitz erabiltzen dugun, lortzen dugun emaitza ez gramatikala da. ${ }^{5}$

\section{* Ikasle batek liburu bakoitza irakurri zuen.}

Ez-gramatikaltasun hau bakoitz kuantifikatzailearen izaera distributiboaren ondorio dela argudiatu izan da (ikus Etxeberria 2001, 2001, 2008, 2012, ikus baita Etxeberria \& Irurtzun prestakuntzan). Izan ere, bakoitz kuantifikatzaileak ez dezake irakurketa distributiboa baizik lortu, (15) adibidean argi geratzen den bezala (ikus halare 5 oin-oharra).

5.- Hiztun batzuren arabera, (14)ko adibidea gramatikala da baldin eta bakoitz espainoleko 'todos y cada uno' bezala interpretatzen badugu. Kasu honetan, lortuko genukeen irakurketa bakarrean subjektuak besarkadura zabala lortuko luke objektuaren gainetik, hau da, perpausaren interpretazioa (13)koaren berdina litzateke. Halere, euskal hiztun gehienak ados daude (14)ko adibidearen ez-gramatikaltasunarekin. 
Neska bakoitzak abesti bat abestu zuen

a. $\sqrt{ }$ distributiboa: neskek banaka abestu zuten

b. * kolektiboa: neskek elkarrekin abestu zuten (e.g. koru batean)

Halere, badira euskaraz ere anbiguotasuna sortzen dituzten bi kuantifikatzailedun (edo kuantifikatzaile/indefinitu) perpausak. Har dezagun (15)eko perpausa, eta alda dezagun subjektu posizioan agertzen den bakoitz kuantifikatzaile unibertsal distributiboa guzti kuantifikatzaile unibertsalarengatik. Aldaketa hau eta gero, (16)ko perpausa gutxienez bi modutara interpretatu daiteke: (i) irakurketa distributiboa: nesken multzoko kide bakoitza abesti bat (espezifikoa ala ez-espezifikoa) abesteko gertaera baten agente izango da, (ii) irakurketa kolektiboa: neska guztien multzoa abesti bat abesteko gertaera bakar baten agente izango da.

(16) Neska guztiek abesti bat abestu zuten

a. $\sqrt{ }$ distributiboa: neskek banaka abestu zuten

b. $\sqrt{ }$ kolektiboa: neskek elkarrekin abestu zuten (e.g. koru batean)

Goiko (16) adibidean gertatzen denarekin kontrajarriz, (17) bezalako perpaus batean subjektu posizioan agertzen den kuantifikatzailearen fokalizatzeak (16) adibiderako deskribatu dugun irakurketa kolektiboa ezabatzen du eta irakurketa distributiboa baino ez du uzten aukera bezala. ${ }^{6}$ Gogoan izan euskarazko galdegaiak aditz aurreko posizioan agertu behar duela, ohar zaitezte (16) eta (17) adibideetako hitz-hurrenkera ez dela berdina, batean Subjektu-Objektu-Aditz (SOA) hurrenkera dugun bitartean bestean Subjektu-Aditz-Objektu SAO hurrenkera dugu (ikus Altube 1923, de Rijk 1978, Mitxelena 1981, Etxepare \& Ortiz de Urbina 2003, Uriagereka 1999, Elordieta 2001, Arregi 2003, Irurtzun 2007, Etxepare \& Uribe-Etxebarria 2008).

(17) Neska [GUZTIEk] $]_{\mathrm{F}}$ abestu zuten abesti bat.

a. $\sqrt{ }$ distributiboa: neskek banaka abestu zuten

b. * kolektiboa: neskek elkarrekin abestu zuten (koru batean)

Beraz, badirudi, proiektu honek ikertzeko asmoa duen bezala, kuantifikatzailearen fokalizazioak perpausak berez lortu ditzakeen irakurketetan eragina duela: galdegaiak perpausaren irakurketa anbiguoa desegiten du, hau da, anbiguotasuna ezabatzen du; cf. Etxeberria \& Irurtzun (prestatzen) analisi posible baterako.

\subsection{Kuantifikatzaile ahulak}

6.- Ohartu bedi irakurlea (15)eko adibidean subjektu posizioan agertzen den bakoitz kuantifikatzailea fokalizatzeak ez duela irakurketa kolektiboa baimentzea ekartzen. 
Milsark-ek (1974, 1977) bi kuantifikatzaile mota desberdintzen ditu, sendoaketaahulak, eta diagnosi sintaktiko batzuk eskaintzen ditu bi kuantifikatzaile mota hauek desberdintzeko. Adibidez, kuantifikatzaile ahulak perpaus existentzial deituetan agertu daitezkeenak dira, sendoak aldiz emaitza ez-gramatikalak edo arraroak ematen dituzten testuinguru hauetan (efektu hau definitutasun efektua 'definiteness effect' bezala ezagutzen da; ikus halere McNally 1992, 2009, Francez 2007, 2009 efektu honen kontrako argudioetarako).
a. Badira mutil batzuk/zenbait/asko/gutxi belardian
b. * Badira mutil guztiak/denak/gehienak belardian

Euskarako kuantifikatzaile ahulen artean, batzuk, zenbait, asko, edo gutxi aipatu ditzakegu adibide moduan. Kuantifikatzaile sendoen artean berriz, guzti, gehien, den aipatu ditzakegu adibide moduan (ikus Etxeberria 2005, 2012 deskribapen zabalago baterako).

Kuantifikatzaile ahul deituak anbiguoak direla asumitzen da irakurketa kardinal baten eta irakurketa proportzional baten artean (cf. Milsark 1974, 1977; ikus baita ere Partee 1988, Diesing 1992, de Hoop 1992, 1995, Ladusaw 1994, Cohen 2001, Zucchi 1995 eta artikulu hauetan aurkitu daitezkeen erreferentziak). Har ezazue (19)ko adibidea batzuk bezalako kuantifikatzaile ahul baten bi irakurketen erakusleiho bezala.
Ume batzuk saskibaloian jolasten ari dira.
a. $\sqrt{ }$ kardinala
b. $\sqrt{ }$ proportzionala

Irakurketa proportzionalean, batzuk kuantifikatzaile ahula ume batzuk, beste batzuk ez bezala interpreta daiteke, eta (20) adibideko umeetatik batzuk partitiboaren baliokidea dela esan daiteke. Irakurketa hau umeen multzoa jada ezaguna denean bakarrik da posible, hau da, ume izenak testuinguruan errelebanteak diren umeen multzoa osorik denotatzen du (Ladusaw 1982).

Umeetatik batzuk saskibaloian jolasten ari dira.

Irakurketa kardinalean berriz, ume batzuk ezin daiteke (20)ko umeetatik batzuk partitiboaren baliokidea izan, eta kuantifikatzaile ahulak kantitate bati baino ez dio erreferentzia egiten.

Portaera hau kuantifikatzaile ahul guztien propietate bat dela asumitzen da, eta propietate honen berri emateko nagusiki bi analisi hedatu direla esan genezake: (i) Partee-k (1988) bi interpretazio hauek (kardinala/proportzionala) desberdinak direla argudiatzen du egia-baldintzei dagokienean, eta desberdintasun hau ezin dakiokeela kuantifikatzaileen berezko zehaztugabetasun bati egotzi (contra e.g. Bennet 1974, Hoeksema 1983, Lappin 2000); (ii) Büring-ek (1996) aldiz, ageriko egitura partitiboa agertzen ez deneko irakurketa proportzionalari ikuspuntu pragmatiko batetik gerturatzen zaio. Analisi semantikoarekin alderatuz, analisi pragmatiko honetan kuantifikatzaile ahulak anbiguoak ez direla argudiatzen da eta irakurketa proportzionala 'Mintzagai/Galdegai/Aurrekari Egitura' ('Topic/Focus/ Background Structure) delakoan oinarritzen da

Dena den, eta kontuari zer analisi emango zaion zehazteke utziaz momentuan, proiektu 
honentzat benetan interesgarria dena zera da: batzuk kuantifikatzaile ahula fokalizatzen den momentuan, (21)n erakusten dugun bezala, irakurketa kardinala desagertu egiten da eta ume batzuk proportzionalki baino ezin daiteke interpretatu, hau da, ume batzuk, beste batzuk ez edo umeetatik batzuk bezala.

(21) Ikasle [Batzuk $]_{\mathrm{F}}$ ari dira saskibaloian jolasten.
a. * kardinala
b. $\sqrt{ }$ proportzionala

Bi kuantifikatzailedun perpausetan gertatzen zen bezala (ikus 3.1 atala), kuantifikatzaileen (kasu honetan, kuantifikatzaile ahul baten) fokalizatzeak perpausaren irakurketa anbiguoa (kardinala/proportzionala) desegiten du irakurketa posible bakar bezala proportzionala utziaz.

\subsection{Numeralak}

Argumentu posizioan, (22) adibideko hiru garagardo bezalako izen sintagma numerodunek irakurketa anbiguoak bultzatzen dituzte: (i) gutxienez interpretazioa (gutxienez hiru garagardo), eta (ii) interpretazio zehatza (zehazki hiru garagardo) (cf. Horn 1972; ikus baita ere Geurts 2010). Fenomeno hau beste hizkuntza batzuetara ere hedatzen da (e.g. ingelesa, frantsesa, espainiera, etb.).

Hiru garagardo edan ditut.

a. $\sqrt{ }$ gutxienez hiru garagardo edan ditut

b. $\sqrt{ }$ zehazki hiru garagardo edan ditut

Inplikatura bidez lortzen den gutxienez irakurketa (23) adibidean erakusten duguna da, non perpausaren bigarren zatiak irakurketa zehatza ezabatzen duen.

Hiru garagardo edan ditut, egia esan, zazpi edan ditut.

a. $\sqrt{ }$ gutxienez hiru garagardo edan ditut

b. * zehazki hiru garagardo edan ditut

Berriro ere, proiektu honentzat interesgarria dena zera da: numeroa adierazten duen elementua fokalizatzen dugun momentuan irakurketa posible bakar bezala interpretazio zehatza deitua geratzen zaigula, (24)ko adibideak erakutsi nahi duen moduan.

[HIRU] $]_{\mathrm{F}}$ garagardo edan ditut.

a. * gutxienez hiru garagardo edan ditut

b. $\sqrt{ }$ zehazki hiru garagardo edan ditut

Goiko adibide honetan irakurketa posible bakarra irakurketa zehatza deitua dela (25) adibideak uzten du agerian, izan ere, gutxienez irakurketa behartzen duen jarraipena emanik, perpausa ez-gramatikala bihurtzen da zuzenean.

* [HIRU $]_{\mathrm{F}}$ garagardo edan ditut, egia esan, zazpi edan ditut. 
a. * gutxienez hiru garagardo edan ditut

b. $\sqrt{ }$ zehazki hiru garagardo edan ditut

Beraz, aurreko bi ataletan agertu dugun moduan, numeralak fokalizatzearekin ere pareko efektu bat lortzen dugu, hau da, perpausaren irakurketa posibleetako bat (inplikatura bidez lortzen dugun gutxienez-ko irakurketa hain zuzen ere) desagertu egiten da eta irakurketa zehatza geratzen da aukera bakar bezala.

\subsection{Ezeztapen-kuantifikatzaile elkar-eragitea}

Ingelesez, ezeztapena eta kuantifikatzaile unibertsalak perpaus batean harremanetan jartzen direnean irakurketa anbiguoak bultzatzen dituzte (ikus 3.1 ataleko (7-8) adibideak). Horrela, all the men did not go 'gizon guztiak ez ziren joan' bezalako esaldi batean, kuantifikatzaile unibertsalak besarkadura zabala hartzen duenean lortzen dugun interpretazioa no man went 'ez zen gizonik joan' perpausaren baliokidea da. Bestalde, ezeztapena denean kuantifikatzailearen gainetik besarkadura lortzen duen elementua, perpausa some men went (some did not) 'gizon batzuk joan ziren (beste batzuk ez)' bezala interpretatzen da. Jakina da intonazioak baduela anbiguotasuna ezabatzeko gaitasuna aipatzen ari garen moduko testuinguruetan (ikus 3.1 atala; ikus Giannakidou 1998 grezieraz gertatzen diren antzeko efektu batzuentzat).

Euskaraz, bi hurrenkera sintaktiko daude zeinetan kuantifikatzaileak eta ezeztapena konbinatu daitezkeen: ezeztapena ageriko sintaxian kuantifikatzailarean gainean ala pean agertu daiteke (26) adibidean erakusten denez. Interesgarria halere zera da, edozein dela ere ezeztapenak eta kuantifikatzaileak erakusten duten hurrenkera, ezeztapenak beti hartzen besarkadura zabala kuantifikatzailearen gainetik (ikus Etxeberria 2012). ${ }^{7}$

a. Ikasle guztiak ez dira etorri.

$\sqrt{ }$ ezeztapena > guzti: ikasle batzuk etorri ziren, beste batzuk ez

* guzti > ezeztapena: ez zen batere ikaslerik etorri

b. Ez dira ikasle guztiak etorri.

$\sqrt{ }$ ezeztapena > guzti: ikasle batzuk etorri ziren, beste batzuk ez

* guzti > ezeztapena: ez zen batere ikaslerik etorri

Jarraian esango dudana sistematikoki aztertua izan ez den intuizio bat baino ez bada ere, badirudi kuantifikatzaile sintagmako kuantifikatzailea fokalizatzen dugunean (ezeztapenkuantifikatzaile hurrenkera edozein dela ere) lortzen dugun irakurketa posible bakarra kuantifikatzaileak ezeztapenaren gainetik besarkadura hartzen duenekoa dela (i.e. no student came 'ez zen batere ikaslerik etorri'), (27) adibidean adierazten dugun bezala.
a. Ikasle $[\mathrm{GUZTiAk}]_{\mathrm{F}}$ ez dira etorri.
* ezeztapena > guzti: ikasle batzuk etorri ziren, beste batzuk ez

7.- Euskaraz ez da existitzen ingeleseko not every 'ez guztiak' kuantifikatzailearen parekorik, ikus Etxeberria (2012) 
$\sqrt{ }$ guzti > ezeztapena: ez zen batere ikaslerik etorri

b. Ez dira ikasle $[\text { GUZTiak }]_{\mathrm{F}}$ etorri.

* ezeztapena > guzti: ikasle batzuk etorri ziren, beste batzuk ez

$\sqrt{ }$ guzti > ezeztapena: ez zen batere ikaslerik etorri

Kasu honetan, aurreko ataletan agertuarekin (kuantifikatzaile-kuantifikazaile elkar-eragitea; kuantifikatzaile ahulak; numeralak) kontrakotasun ageri bat dago: ez da kuantifikatzailea fokalizatzean interpretazio anbiguodun perpaus bat ez anbiguo bihurtzen dela, baizik perpaus batek (kasu honetan, bik) lortzen duen interpretazio irauli egiten dela eta hasera batean ezinezkoa litzatekeen irakurketa bat bultzatzen duela galdegaiaren erabilerak. Halere, eta desberdintasunak desberdintasun, galdegaiak bultzatzen duen efektu hau oso interesgarria da proiektu honentzako.

Atal honetan deskribatu ditugun lau fenomenoek badute antzekotasun nabari bat: galdegaiak kuantifikatzaileen interpretazioan eragiten du, bai besarkadurari dagokion ikuspuntu batetik (i.e. kanpo ikuspegia) baita ere barne ikuspegi batetik, i.e. kuantifikatzaileen propietateei begiratuaz. Normalean galdegaiak perpaus anbiguo bati anbiguotasuna ezabatzen dio, soilik irakurketa bakarra eginaz posible—azken kasu hau alde batera utziaz, izan ere kasu honetan aurretik posible ez zen irakurketa bat sortzen baitu galdegaiaren erabilerak.

Ohar bedi irakurlea artikulu honetan euskarazko adibideak baino ez ditugula eman aztertu behar ditugun gaiak azaltzean—eta gai hauek ikerketa sakonago bat behar dutela esatearekin proiektuaren zereginetako bat agerian geratzen da. Halere, eta proiektu honen helburuetako bat ikerketa konparatibo bat egitea dela kontutan izanik, oso garrantzitsua izango da ikustea euskararako deskribatu ditugun intuizio horiek (non galdegaiak besarkadura harremanetan eragiten duen eta posibleak ez diren besarkadura harremanak sortzen dituen) frantsesez, espainolez, ingelesez edo grezieraz berdin betetzen ote diren. Are gehiago, proiekturako bilduko diren datuen azterketa sakonak aukera ezin hobea eskainiko digu ikerketa arlo honen ikuspegi berri, berriztatzaile eta orokorrago bat sortzeko.

\section{Metodologia}

Kuantifikatzaileen besarkadura hainbat faktorek eragiten duten fenomeno bat da, eta faktore hauek guztiak kontuan izan beharrekoak dira datuak jasotzeko garaian: informazio egitura/prosodia, aditz motak, hitz hurrenkera, hurrenkera aurrekotasuna, funtzio gramatikala, propietate tematikoak, distributibotasuna/kolektibotasuna, etb. Esan bezala, faktore hauek guztiak kontuan hartuak izango dira testak prestatzerakoan. Garrantzitsua izango da baita ere zehaztea ikertuko ditugun hizkuntzetan besarkadura anbiguotasunik baden, eta erantzuna baiezkoa bada, zehaztu beharko da zein baldintzetan ematen diren anbiguotasun hauek. Anbiguotasunik baldin bada, hiztun batek irakurketa anbiguoei anbiguotasuna kentzeko erabiltzen dituen baliabideak zein diren testatuko dugu (ekoizpen eta pertzepzio testen bitartez). Elkarrizketatuko ditugun hiztun guztiak beraien ama-hizkuntzan elkarrizketatuak izango dira.

\subsection{Testak}

\subsubsection{Kontraesanaren testa}


Testatua izan behar duen perpaus bati segida bat sortuko diogu eta segida hori kontraesan bat izango da baldin eta testatuko den perpausak ez badu besarkadura erlazio jakin bat erakusten. Test honen bitartez ondorioztatu ahal izango dugu bi kuantifikatzailedun perpaus bat benetan anbiguoa den ala ez. Test hau 4 atalean aurkeztutako edozein fenomenori aplikatu dakioke. Adibide moduan, har ezazue (28) adibidea: lehenengo perpausa ulertzeko modu bakarra most of the students 'ikasle gehienek'-ek kuantifikatzaile unibertsalaren gainetik besarkadura zabala duenekoa dela, hau horrela izanik, bigarren perpausak kontraesana sortzen du bultzarazten duen irakurketak lehenengo zatian lortu ezin duen besarkadura harremanari egiten baitio erreferentzia.

(28) * Most of the students read every book. Thus, each book has been read by a possibly different majority of students that has read it.

* 'Ikasle gehienek liburu guztiak irakurri dituzte. Ondorioz, liburu bakoitza ikasleen gehiengo desberdin batek irakurri izan da'

\subsubsection{Galdera/erantzun testa}

Test hau ere bi kuantifikatzailedun perpaus bat anbiguoa den ala ez jakiteko erabili daiteke, eta ondorioz 4 atalean aurkeztutako edozein fenomenori aplikatu dakioke. Galdera batek besarkadura harreman jakin bat izateak, galdera horren erantzunak ere besarkadura harreman berdina izan dezan bultzatzen du. Gauzak horrela, erantzun batek galderak ezarritako besarkadura harremanaren kontrakoa erakusten badu, erantzun egoki bat emateko baldintza urratuko du. Har dezagun (28) adibidea erantzuna bailitzan, erantzun honek erantzun egoki bat emateko baldintza urratuko du (29a) adibidean. Ez ordea (29b)ko adibidean.

a. *How many books are such that a possibly different majority of students has read it? Most of the students read every book.

b. How many students are such that they have read every book?

Most of the students read every book.

\subsubsection{Marrazkiak/argazkiak}

Hau ekoizpen esperimentu bat da non subjektuak prosodia erabiltzera behartuak dauden besarkadura anbiguotasunak ekiditeko. Subjektuei esaldi batzuk emango zaizkie altuan irakurri ditzaten eta esaldi bakoitzaren aldamenean bi marrazki/argazki emango zaizkie (ikus 1 irudia). Test honetan, parte hartzaileei bi irakurketa posibleetatik bat adierazten saiatzeko eskatzen zaie, eta ematen duten erantzuna grabatu egingo zaie. Grabatuak izango

\section{Every dice cup covers a color}
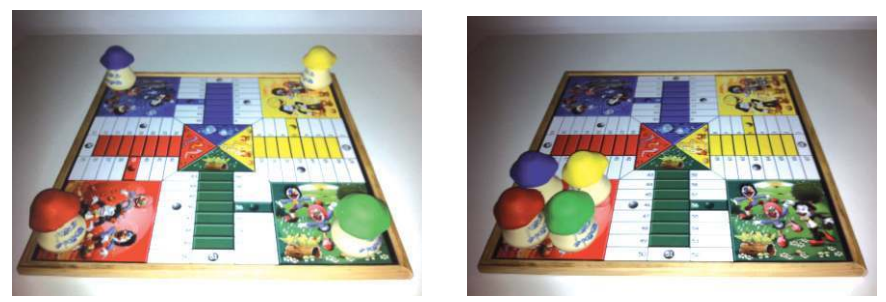
diren parte hartzaileei esango diegu beraien grabaketak beste jende batek entzungo dituela eta hauek saiatu beharko dutela beraiek adiera nahi zuten irakurketa zein den asmatzen.

1 irudia

Every dice cup covers a color 'Kubo guztiek kolore bat tapatzen dute'

\subsubsection{Testuinguru desanbiguatzaileak}

Testuinguru desanbiguatzaileen test hau ekoizpen esperimentu bat izango da. Bertan, galdetegi bat prestatuko dugu, eta horretarako, hurrenkera berdina izango duen (e.g. \# every^girl^sang^a^song\# 'neska guztiek abesti bat abestu zuten') perpaus pare minimo bat txertatuko dugu testuinguru desanbiguatzaileak eskainiko dituen egi itxurako elkarrizketa batean. Euskaraz ezin izango dugu test hau erabili, izan ere, hizkuntza honetan elementu bat galdegai posizioan agertzeak hitz-ordenean aldaketa baitakar. Test honetan ere, 5.1.3 atalean aurkeztu dugun Marrazkiak/argazkiak testean bezala, marrazkiak/argazkiak erabili ditzakegu. Kasu honetan, perpaus bakoitza bi argazkirekin eman beharrean, anbiguotasuna ezabatuko lukeen argazki batekin emango litzateke.

\section{Datu-basea}

Datuen bilketatik sortuko dugun datu-basea ataletan banatua egongo da: orokorra, testetan bildutako datuak, fitxategiaren deskribapena, dokumentu atxikia. Atal hauetan egingo diren grabaketen inguruko informazio zehatza bilduko dugu (identifikatzailea, izenburua, arduraduna, elkarrizketatzailea, data bilketa, luzera, formatua, tamaina, erabilera eta erreprodukzio eskubideak, testa) XML editatzaile baten (Oxygen, XMLSpy) bitartez, modu honetara trukaketak eta ustiaketa erraztuko ditugu. Bigarren pausu batean, datu-baseari etiketak gehituko zaizkio. Sortuko dugun datu-basea, ikerketa proiektuari amaiera ematean egingo da publiko.

\section{Erreferentziak}

Altube, S., 1929, Erderismos, Bermeo: Euskaltzaindia.

Aoun, J. \& N. Hornstein. 1985. Quantifier types. Linguistic Inquiry 16, 623-637.

Aoun, J. \& A. Li. 1989. Scope and constituency. Linguistic Inquiry 20, 141-172.

1993. Syntax of Scope. Cambridge, MA: MIT.

Arregi, K. 2003. Focus on Basque Movements. PhD Dissertation. MIT.

Artiagoitia, X. 1997. DP predicates in Basque. In University of Washington Working Papers on Linguistics 15, A. Taff (ed), 161-198. Washington: University of Washington.

--- 1998. Determinatzaile Sintagmaren Hipotesia Euskal Gramatikan. Uztaro 27: 33-61.

--- 2002. The functional structure of Basque noun phrases. In X. Artiagoitia et al. (eds), Erramu Boneta: Festschrift for Rudolf P. G. de Rijk, , 73-90. Vitoria-Gasteiz: ASJU.

--- 2006. Euskarazko izen sintagma: arkitektura eta egitura funtzionala. Unpublished manuscript. UPV/EHU. 
--- The DP hypothesis in the grammar of Basque. In NPs and Nominalizations in Basque: Syntax and Semantics, U. Etxeberria et al. (eds.), 21-78. Amsterdam: John Benjamins.

Azkue, R.M., 1923-5, Morfología Vasca Bilbo: La Gran Enciclopedia Vasca.

Bach, E. et al. 1995. Quantification in natural languages. Dordrecht: Kluwer.

Baltazani, M. 2002. Quantifier scope and the role of intonation in Greek. PhD diss.: UCLA.

Barwise, J. \& R. Cooper. 1981. Generalized quantifiers and natural language. Linguistics \& Philosophy 4, 159-219.

Beghelli, F. (1993). The phrase strcture of quantifier scope. PhD diss.: UCLA.

Beghelli, F. \& T. Stowell. 1997. Distributivity and negation: The syntax of each and every. In A. Szabolcsi (ed.), Strategies for scope taking. 71-108.

Belletti, A., 2004, "Aspects of the low IP area", in L. Rizzi (ed.), The Structure of IP and CP. The Cartography of Syntactic Structures, vol. 2, New York: Oxford University Press.

Bennet, M. 1974. Some Extensions of a Montague Fragment of English. PhD dissertation, UCLA.

Brody, M. 1990. Remarks on the order of elements in the Hungarian focus field. Approaches to Hungarian 3; Structures \& Arguments, edited by I. Kenesei, 95-122. JATE, Szeged

Brody, M. \& A. Szabolcsi. 2003. Overt scope in Hungarian. Syntax 6, 16-51.

Büring, D. 1996. A Weak Theory of Strong Readings. In Galloway, T. \& J. Spence (eds.), Proceedings of SALT VI, Ithaca, NY: CLC Publications, Cornell University. 17-34.

--- 1997. The great scope inversion conspiracy. Linguistics \& Philosophy 20, 175-194.

--- 1999. Topic. In P. Bosch \& R. van der Sandt (eds.), Focus: linguistic, cognitive, and computational perspectives, Cambridge (UK): Cambridge University Press, 142-165.

--- 2003. On D-Trees, Beans, and B-Accents. Linguistics \& Philosophy 26:5, 511-545.

Cinque, G. 1993. A null theory of phrase and compound stress. Linguistic Inquiry 24: 239297.

Cohen, A. 2001. Relative Readings of Many, Often, and Generics. Natural Language Semantics, 9. 41-67.

Diesing, M. 1992. Indefinites. Cambridge, MA: MIT Press.

Eguren, L. 2006. Non-canonical uses of the article in Basque. In Proceedings of the 32nd Annual Meeting of the Berkeley Linguistics Society, M. J. Hauser et al. (eds.). Berkeley.

2012. Predication markers in Basque. In NPs and Nominalizations in Basque: Syntax and Semantics, U. Etxeberria et al. (eds.), 243-266. Amsterdam: John Benjamins.

Eguzkitza, A. 1993. Adnominals in the Grammar of Basque. In Hualde, J. I. \& J. Ortiz de Urbina (eds.), Generative Studies in Basque Linguistics, Amsterdam/Philadelphia: John Benjamins. 163-187.

Elordieta, A., 2001. Verb movement and constituent permutation in Basque, PhD. Dissertation, HIL/Leiden University, LOT Dissertation Series. 
Elordieta, G. \& A. Irurtzun, 2010, "The relationship between meaning and intonation in nonexhaustive answers: evidence from Basque", The Linguistic Review 27-3, 261-291.

Erteschik-Shir, N. 2007. Information Structure: The Syntax-Discourse Interface, New York: Oxford University Press.

Etxeberria, U. 2002. La Interpretación de los Cuantificadores del Euskara. Interlingüística, XII, 53-70.

--- 2005. Quantification and Domain Restriction in Basque. PhD diss.: U. Basque Country.

--- 2008. On quantification in Basque and on how some languages restrict their quantificational domain overtly. In Matthewson, L. (ed.), Quantification: A crosslinguistic perspective. Emerald. 225-276.

--- 2009. Contextually restricted quantification in Basque. In Giannakidou, A. \& M. Rathert (eds.), QP Structure, Nominalizations, and the Role of DP, Oxford: Oxford University Press.

--- 2012. Quantification in Basque. In E. Keenan \& D. Paperno (eds.), Handbook of quantifiers in natural languages. Amsterdam: Springer

Etxeberria, U. \& A. Giannakidou. 2009. Contextual restriction and the definite determiner. In F. Recanati et al (eds.), Context-Dependence, Perspective $\&$ Relativity in Language and Thought. Berlin: Mouton. 93-126.

Etxeberria, U. \& A. Giannakidou. Agertzeko. D-heads, domain restriction, and variation: from Greek and Basque to St'át'imcets Salish. In Schürcks, L., Etxeberria, U., A. Giannakidou (eds.), The Structure of NP/DP in Slavic and beyond. Berlin: Mouton de Gruyter.

Etxeberria, U. \& A. Irurtzun. 2004. Prosodic features with semantic interpretation. In Crouzet et al (eds.), Proceedings of JEL 2004. Nantes: AAI. 95-101.

Etxeberria, U. \& A. Irurtzun. Prestakuntzan. Information structure and quantification. Ms. CNRS-IKER

Etxepare, R. 1998. A case for two types of focus in Basque. In E. Benedicto, M. Romero \& S. Tomioka (eds.), UMOP 21: Proceedings of the workshop on focus, Amherst: GLSA, 65-81.

Etxepare, R. \& J. Ortiz de Urbina. 2003. Focalization. In J. I. Hualde \& J. Ortiz de Urbina (eds.), A grammar of Basque, Berlin: Mouton de Gruyter, 459-515.

Etxepare, R. \& M. Uribe-Etxebarria. 2008. Negation and Focus in Spanish and Basque. In X. Artigoitia \& J. Lakarra (eds.), Gramatika Jaietan. Patxi Goenagaren omenez. Bilbao: University of the Basque Country. 287-310.

Fox, D. 2000. Economy and semantic interpretation. Cambridge, MA: MIT.

Francez, I. (2007). Existential Propositions. PhD thesis, Stanford.

(2009). Existentials, predication, modification. Linguistics and Philosophy 32:1.

Garcia-Murga, F. \& S. Rodriguez. 2003. Konposizionalitatea. In Artiagoitia, X. et al. (eds.), Erramu Boneta: Festschrift for Rudolf P. G. de Rijk, Vitoria-Gasteiz: ASJU, UPV/EHU. 549571.

Geurts, B. 2010. Quantity implicatures. Cambridge: Cambridge University Press. 
Goenaga, P. 1991. Izen Sintagmaren Egituraz. In Memoriae L. Mitxelena Magistri Sacrum, J Lakarra (ed.), 847-865. Donostia: UPV/EHU.

Heim, I. 1982. Semantics of Definite and Indefinite Noun Phrases. PhD dissertation: MIT.

Herburger, E. 2000. What Counts. Focus and Quantification. Cambridge, MA: MIT Press.

Hoeksema, J. 1983. Plurality and Conjunction. In A.G.B. ter Meulen (ed.), Studies in Model Theoretic Semantics, Dordrecht: Foris. 63-83.

van Hoof, H. 2003. The rise in the rise-fall contour: does it evoke a contrastive topic or a contrastive focus?. Linguistics 41-3, 515-563.

de Hoop, H. 1992. Case Configuration and Noun Phrase Interpretation, PhD dissertation: University of Groningen. [Published 1997 by Garland Publishing Inc., New York.]

1995. On the Characterization of the Weak-Strong Distinction. In E. Bach, et al. (eds.), Quantification in Natural Language, Dordrecht: Kluwer. 421-450.

Horn, L. 1972. On the Semantic Properties of Logical Operators in English. PhD dissertation: UCLA.

Hornstein, N. 1995. Logical Form. From GB to Minimalism. London: Blackwell.

Huang, C.-T. J. 1982. Logical relations in Chinese and the theory of grammar. Ph.D thesis, MIT.

Ioup, G. 1975. The treatment of quantifier scope in a transformational grammar. PhD diss.: University of New York.

Irurtzun, A. 2007. The Grammar of Focus at the Interfaces. PhD dissertation: University of the Basque Country (UPV/EHU).

Jackendoff, R. 1972. Semantic interpretation in generative grammar. Cambridge, MA: MIT.

Jackson, S. 2007. Information, truth, structure, and sound. PhD Diss.: University of Arizona.

Kadmon, N., 2001, Formal Pragmatics: Semantics, Pragmatics, Presupposition, and Focus, Oxford: Wiley-Blackwell.

Keenan, E. \& J. Stavi. 1986. A semantic characterization of natural language determiners. Linguistics \& Philosophy 9 (3): 253-326.

--- 1987. 'A Semantic Definition of “Indefinite NP”. In E, Reuland \& A. G. B. ter Meulen (eds.), In the Representation of (in)definiteness, Cambridge, MA: MIT Press. 286-317.

--- 1996. The Semantics of Determiners. In S. Lappin, S. (ed.), The Handbook of Contemporary Semantic Theory, Oxford: Blackwell Publishers. 41-63.

Keenan, E. \& D. Paperno. 2012. Handbook of quantifiers in natural languages. Amsterdam: Elsevier.

Keenan, E. \& D. Westerståhl. 1997. Generalized Quantifiers in Linguistics and Logic. In J. van Benthem \& A. G. B. ter Meulen (eds.), Handbook of Logic and Language, Elsevier. 839893.

Kennelly, S. D. 2003. The implication of quantification for the role of focus in discourse 
structure. In Göksel A. et al. (eds.), Lingua 113. 1005-1088.

Kiss, K. 1998. Identificational Focus versus Information Focus. Language 74(2), 245-273.

(ed.). 1995. Discourse configurational languages, New York (NY): Oxford University Press.

Kratzer, A. \& L. Selkirk. 2007. Phase theory and prosodic spell-out: the case of verbs. The Linguistic Review 24: 93-135.

Krifka, M. 1998. Scope inversion under the rise-fall contour in German. Linguistic Inquiry 29, 75-112.

Krifka, M. 2004. The semantics of questions and the focusation of answers. In Chungmin Lee, Matthew Gordon \& Daniel Büring (eds.), Topic and focus: A cross-linguistic perspective. Dordrecht: Kluwer. 139-151.

Kroch, A. 1974. The semantics of scope in English. PhD diss.: MIT.

Ladusaw, B. 1994. Thetic and Categorial, Stage and Individual, Weak and Strong. In Harvey, M. \& L. Sautelmann (eds.), Proccedings from Semantics and Linguistic Theory IV, Dept. of Modern Languages, Cornell University, Ithaca. 209-219. Reprinted in Horn, L. R. \& Y. Kato, 2000, Negation and Polarity. Syntactic and Semantic Perspectives, NY: Oxford University Press Inc. 232-242.

Laka, I. 1993. Unergatives that assign ergative, unaccusative that assign accusative. In Papers on case and agreement, J. Bobaljik \& C. Phillips (eds.), 149-172. Cambridge, MA: MIT WPiL.

Lappin, S. 2000. An Intensional Parametric Semantics for Vague Quantifiers. Linguistics \& Philosophy 23. 599-620.

Liu, F-S. 1990. Scope and specificity. Amsterdam: John Benjamins.

López, L. 2009. A Derivational Syntax for Information Structure, Oxford: OUP.

Martí, L. 2001. Intonation, scope and restriction on quantifiers. In Megerdoomian, K. \& L. Bar-el (des.), Proceedings of WCCFL 20. Somersville, MA: Cascadilla Press. 372-385.

McNally, L. (1992). An Interpretation for the English Existential Construction, Doctoral dissertation, University of California, Santa Cruz. [Published 1997 by Garland NY]

--- (2009). 'Existential sentences', in Maienborn, C., K. von Heusinger \& P. Portner, (eds). Semantics: An International Handbook of Natural Language Meaning. Berlin: de Gruyter.

Matthewson, L. 2001. Quantification and the Nature of Crosslinguistic Variation. Natural Language Semantics 9. 145-179.

--- 2008a. Quantification: A crosslinguistic perspective. London: Emerald.

--- 2008b. 'Pronouns, presuppositions, and semantic variation', in T. Friedman and S. Ito (eds.), SALT XVIII, Ithaca, NY: Cornell : 527-550.

--- 2013. 'Strategies of quantification in St'át'imcets, revisited', in Gil, K.-H. and G. Tsoulas (eds.) Strategies of Quantification, Oxford: Oxford University Press.

May, R. 1977. The grammar of quantification. PhD diss.: MIT.

1985. Logical Form: Its structure and derivation. Cambridge, MA: MIT. 
Milsark, G. 1974. Existential Sentences in English, PhD dissertation: MIT. [Published 1979 by Garland Publishing Inc., New York.]

--- 1977. Toward an Explanation of Certain Peculiarities of the Existential Construction in English. Linguistic Analysis 3-1. 1-28.

Mitxelena, K. 1981. Galdegaia eta mintzagaia euskaraz. In Euskal linguistika eta literatura: Bide berriak, Bilbo: Deustuko Unibertsitatea, 57-81.

Montague, R. 1974. The proper treatment of quantification in ordinary English. In Hintikka et al. (eds.), Approaches to Natural Language. Dordrecht: Reidel.

Ortiz de Urbina, J. 1989. Some parameters in the grammar of Basque, Dordrecht: Foris.

Ortiz de Urbina, J. 1995. Datibo komunztaduraren gainean. In J. Lakarra \& R. Gomez (eds.) Euskal Dialektologiaren Kongresua. Vitoria-Gasteiz: ASJU (UPV/EHU).

Pafel, J. 2005. Quantifier Scope in German. Amsterdam: John Benjamins.

Partee, B. 1987. Noun Phrase Interpretation and Type-Shifting Principles. In Groenendijk, J., D. de Jongh, \& M. Stokhof (eds.), Studies in Discourse Representation Theory and the Theory of Generalized Quantifiers, Dordrecht: Foris. 115-143.

--- 1988. Many Quantifiers. In Powers, J. \& K. de Jong (eds.), Proceedings of Fifth ESCOL, The Ohio State University, Columbus. 383-402.

Rebuschi, G. 1983. A note on focalization in Basque. In ASJU-International Journal of Basque Language and Linguistics 4-2, 29-42.

Rebuschi, G. \& L. Tuller (eds.) 1999. The grammar of focus, Amsterdam: John Benjamins.

Reinhart, T. 1995. Interface strategies. OTS working papers in linguistics, University of Utrecht

--- 1997. Quantifier scope: How labor is divided between QR and choice function. Linguistics E Philosophy 20, 335-397.

--- 2006. Interface Strategies: Reference-set Computation. Cambridge, MA: MIT.

de Rijk, R. 1978. Topic Fronting, Focus Positioning, and the Nature of Verb Phrase in Basque. In Cansen, F. (ed.), Studies in Fronting. Leiden: Peter de Ridder Press. 81-112. Reprinted in de Rijk (1998), De Lingua Vasconum: Selected Writings, Bilbo: ASJU (UPV/EHU). 251-270.

Rizzi, L. 1997. The fine structure of the left periphery. In L. Haegeman (ed.), Elements of grammar, Dordrecht: Kluwer, 281-337.

Rooth, M. 1985. Association with Focus. PhD dissertation: UMass.

Ruys, E. G. \& Y. Winter. 2011. Quantifier scope in formal linguistics. In D. Gabbay (ed.), Handbook of Philosophical Logic - Second Edition. Amsterdam: Springer.

Schwarzschild, R. 1999. GIVENness, avoid F and other constraints on the placement of accent. Natural Language Semantics 7: 141-177

Szabolcsi, A. 1997. Ways of scope taking. Amsterdam: Kluwer.

--- 2000. The syntax of scope. In In M. Baltin \& C. Collins (eds.), Handbook of Contemporary 
Syntactic Theory. London: Blackwell (2000)

--- 2010. Quantification. Cambridge: Cambridge University Press.

Tajsner, P. 2008. Aspects of the grammar of focus : a minimalist view, New York: Peter Lang.

Uriagereka, J. 1999. Minimal Restriction on Basque Movements. Natural Language E Linguistic Theory 17. 403-444.

Vallduví, E. 1990. The Informational Component. PhD diss.: University of Pennsylvania.

Vallduví, E. 1993. Information packaging: a survey. Ms. University of Edinburgh.

Westerståhl, D. 1984. Determiners and Context Sets. In J. van Benthem \& A. G. B. ter Meulen (eds.), Generalized Quantifiers in Natural Languages, Dordrecht: Foris. 45-71.

Zubizarreta, M. L. 1998. Prosody, focus and word order, Cambridge: MIT Press.

Zucchi, A. 1995. The Ingredients of Definiteness and the Definiteness Effect. Natural Language Semantics 3. 33-78.

Zwarts, J. 1986. Categoriale Grammatica en Algebraische Semantiek. Een studie naar negatie en polariteit in het Nederlands. PhD thesis, University of Groningen. 